\title{
Transnational Diaspora: Interaction of Jewish Elites and the Poliakovs
}

\author{
Ch. Y. Freeze, G. L. Freeze
}

For citation: Freeze Ch.Y., Freeze G.L. Transnational Diaspora: Interaction of Jewish Elites and the Poliakovs. Vestnik of Saint Petersburg University. History, 2020, vol.65, iss. 1, pp.108-120. https://doi.org/10.21638/11701/spbu02.2020.106

Recently historians have come to recognize the need to go beyond national history and to acknowledge the transnational, which became so important in the globalization of 1870-1914. It is no less essential to expand the focus beyond economics alone and to consider the array of other factors, especially cultural and religious, that were ever more powerful and capable of transcending national boundaries. One key analytic framework in recent scholarship is "intimacy," which focuses on the social nexus and political connections that were so critical in the rise of the new industrial-financial elites across Europe. This paper examines the case of the Poliakovs, a Russian Jewish family that began as petty merchants in the Pale of Settlement but became leading bankers, railroad barons, and factory owners in late Imperial Russia. Drawing on family records (especially the diaries of two family members) but also an array of archival and printed sources (including the societal pages of leading French and German newspapers), this paper examines: a) how the Poliakovs learned to "perform" successfully in aristocratic high society; b) how and why that performance was so critical to the family's perceived affluence (and hence the credibility of their various businesses); c) how the transnational served simultaneously to cement the family's status in the Russian elite and to become part of the Jewish diaspora (not only to promote business but to avoid intermarriage). This was a family business in the fullest sense: the family was the business.

Keywords: Jews, transnational, intimacy, sociability, philanthropy, the Poliakovs.

ChaeRan Y. Freeze - PhD, Professor of History, Brandeis University, GF11, Waltham, Massachusetts, USA; cfreeze@brandeis.edu

Шаеран Ю. Фриз - PhD, профессор истории, Брандейский университет, США, Уолтем, Массачусетс, США; cfreeze@brandeis.edu

Gregory L. Freeze - PhD, Professor of History, Brandeis University, GF11, Waltham, Massachusetts, USA; Visiting Research Fellow, St. Petersburg State University, 7-9, Universitetskaia nab., St. Petersburg, 199034, Russian Federation; freeze@brandeis.edu

Грегори Л. Фриз - PhD, профессор истории, Брандейский университет, США, Уолтем, Массачусетс, США; приглашенный исследователь, Санкт-Петербургский государственный университет, Российская Федерация, 199034, Санкт-Петербург, Университетская наб., 7-9; freeze@brandeis.edu

This research was supported by grant No. 15-18-00119 from the Russian Science Foundation. Исследование выполнено при поддержке гранта Российского научного фонда № 15-18-00119.

(c) Санкт-Петербургский государственный университет, 2020 


\title{
Транснациональная диаспора: взаимодействие еврейской элиты и семьи Поляковых
}

\author{
Ш. Ю. Фриз, Г.Л. Фриз
}

Для цитирования: Freeze Ch. Y., Freeze G.L. Transnational Diaspora: Interaction of Jewish Elites and the Poliakovs // Вестник Санкт-Петербургского университета. История. 2020. Т. 65. Вып. 1. C. 108-120. https://doi.org/10.21638/11701/spbu02.2020.106

Европейские историки уже давно признали, что нельзя ограничить анализ в рамках традиционной национальной истории, а следует изучать транснациональную динамику, т.е. процессы, которые сопровождали глобализацию 1870-1914 гг. Не менее важно и то, что в последнее время историки стали изучать не только чисто экономические факторы, а обращать внимание на другие аспекты, в первую очередь культурные и этноконфессиональные. Особенно плодотворной является концепция «интимность», или личный момент, т.е. социальные и политические связи, которые были столь важными в успехе новых индустриально-финансовых элит. Не только капитал, банковские структуры и бизнес-планы, но и этноконфессиональные связи сыграли важную роль в деятельности и успехах новых элит в эпоху глобализации. Данная работа изучает известную русско-еврейскую семью Поляковых, которые происходили из мелких купцов в черте еврейской оседлости и стали ведущими банкирами, железнодорожными королями и владельцами заводов и фабрик как в России, так и за границей. Без ассимиляции Поляковы не только использовали свое богатство, но и научились подражать поведению и культурной деятельности русских и западноевропейских еврейских элит. На основе семейных документов (в первую очередь дневников двух членов семьи), а также архивных и печатных источников (включая светскую хронику в ведущих западноевропейских газетах) настоящая статья предлагает ответы на следующие вопросы: а) как Поляковы научились исполнять нужные роли в элитном обществе; б) почему такой статус и такая роль были столь важными для восприятия семейного благополучия (и кредитоспособности семейного бизнеса); в) как транснациональность подкрепила положение Поляковых не только дома, но и за границей (и тем самым помогла избежать межэтнических браков). Это был «семейный бизнес» в полном смысле этого слова - семья и была бизнесом.

Ключевые слова: евреи, транснациональность, интимность, социальность, филантропия, Поляковы.

The meteoric rise of Iakov, Samuel, and Lazar Poliakov — from a family of petty merchants in the Pale of Settlement to international bankers and railroad moguls - has elicited comparisons with the famous Rothschilds. The diaries of Iakov Poliakov and Lazar's eldest daughter, Zinaida Poliakova $(1863-1952)^{1}$, show how a Jewish family not only accumulated great wealth, but integrated into Russian and European high society and did so without converting to Christianity. The key to success was a transnational "political economy of intimacy" - a complex calculus of capital, aristocratic sociability, cultural patronage, and philanthropy ${ }^{2}$. Critical to this political intimacy was the role of the Poliakov women

${ }^{1}$ Poliakov I. Istoriia semeinykh nachinanii [s] 1748 goda (unpublished manuscript in the Central Archives of the History of the Jewish People, Jerusalem, Israel; for details on Zinaida Poliakova's life and diaries, see: Freeze C. Y. A Jewish Woman of Distinction: The Life and Diaries of Zinaida Poliakova. Waltham, 2019.

${ }^{2}$ For the concept of a "political economy of intimacies," see: Lowe L. The Intimacies of Four Continents. Durham; London, 2015. P. 18. 
(Zinaida's mother and the three daughters), who were hosts of an aristocratic salon and munificent patrons of the arts. The Poliakovs helped to create a new imperial elite culture, one that was rossiiskii and not just ethnic russkii ${ }^{3}$, hence one that was compatible with their Jewishness. That supra-ethnic culture enabled an affective identity with Russia, making it possible for elites - Russians and Jews - to socialize and transcend ethnic barriers.

Recent scholarship has challenged the traditional assumption that the intimate is separate from "the state and the market" and that intimacy "belongs to local level and private sphere"4. Rather, Ann Laura Stoler has argued that "to study the intimate is not to turn away from structure of dominance, but to relocate their conditions of possibility" Intimacy, in short, provides an analytic framework to illuminate how broader historical processes (such as the development of capitalism and ethno-confessional politics) interacted with the personal relationships, as in the case of the Poliakovs and their network of Russian and European elites. Their intimacy in Russia but also abroad afforded the Poliakovs unprecedented business opportunities, cultural patronage, and even political influence. Crucial too was the transnational diaspora, which not only was valuable its business networking, but also enabled the Poliakovs to preserve the Jewishness - i.e., avoid intermarriage and sustain the Jewish half of their identity.

\section{Political Capital}

The Poliakovs, who originally hailed from the small town of Dubrovno (Mogilev province), prospered not only because of their business acumen but also because of their ties with officials in the provinces and later in the capital. Like the first-generation Jewish entrepreneurs (such as the Gintsburgs) who left the Pale of Settlement during the Great Reforms, the Poliakovs took advantage of the opportunities offered by a Russian state keen to consolidate its power in the western provinces ${ }^{6}$. The Poliakovs first served as tax farmers and contractors, but their fortunes rose exponentially when I. M. Tolstoi (Minister of Posts and Telegraphs) hired Samuel to manage a vodka distillery on his estate and several postal stations in Riazan (which then Samuel subcontracted to Lazar). Tolstoi's patronage in turn led to lucrative contracts for Samuel to build railroads ${ }^{7}$, including the BenderGalats line for the military (for 8,546,153 paper rubles) ${ }^{8}$. In 1878, Iakov, who oversaw the construction, proudly described how he met the Tsesarevich Alexander (the future Alexander III) during the train's maiden voyage: "The heir shook my hand $\langle\ldots\rangle$ and thanked me very courteously for the successful trip, [and] asked about the health of my brother [Samuel, at the time ill]. I presented him with the album [of the Bender-Galats railroad]. He remembered that I had also presented him with an album in Cherkassy. He began to examine the album at great length and asked for explanations and clarifications. This

3 The distinction here is critical, if not easily rendered in English. Whereas "russkii" is specifically "ethnic Russian," the term "rossiiskii" derives from the Latin and refers to the Russian state; it is currently used in the supra-ethnic sense to distinguish "Rossiane" (citizens of the Russian Federation) as more inclusive than "Russkie" (ethnic Russians), the latter comprising 81 percent of the population (2010 census).

${ }^{4}$ Wilson A. Infrastructure of Intimacy // Signs. 2016. Vol. 42, no. 2. P. 250.

5 Ibid. P. 250; Stoler A. L. Intimidations of Empire: Predicaments of the Tactile and Unseen // Haunted by Empire: Geographies of Intimacies in North American History / ed. by A. L. Stoler. Durham, 2006. P. 1-22.

${ }^{6}$ Poliakov I. Istoriia semeinykh nachinanii. L. 17.

${ }^{7}$ For details, see: Anan'ich B. V. Bankirskie doma v Rossii. Moscow, 2006. P. 101.

8 Ibid. P. 101. 
continued for more than half an hour and then he again shook my hand"9. To the end, the Poliakovs were staunch supporters of the autocracy and cherished memories of such intimate encounters with the royal family.

The two older Poliakov brothers were successful, but Lazar surpassed both in wealth and influence. In 1870, Lazar established his own banking house in Moscow and made it the hub for an empire of joint-stock and commercial banks, railroad and insurance companies, and multiple enterprises in Russia and abroad. While traditional Moscow banks catered to established industries in the city and shunned the stock market and risky new ventures, the Poliakovs offered credit and higher returns on investments. The Poliakov success, predictably, antagonized the competition, notably the Old Believers. When the Riabushinskiis opened a branch in St. Petersburg, they warned their employees about the dangers of the capital city, where "exchange orgies and unprincipled brokers, mainly of Jewish origin $\langle\ldots\rangle$ [are] masters of the game" ${ }^{10}$. Reinforced by their traditional animosity toward the state and tsar ${ }^{11}$, Old Believers resented Lazar Poliakov's close ties to government officials at the highest levels. Not only Old Believers, but others took exception to the rising influence of the Poliakovs. The nobleman Dmitri Nikiforov, for example, invoked the suspicion of unfair Jewish influence to explain his failure, along with four other partners, to establish a Moscow Land Bank. Despite assurances from state officials, Nikiforov learned that a rival group linked to Poliakov had submitted the exact same proposal to the Ministry of Finance, and that the competitor adroitly persuaded two of his partners to join them. One of them warned Nikiforov to abandon his project and "not to struggle against such forces as Prince [Vladimir] Cherkasskii ${ }^{12}$ and the railroad man [Lazar] Poliakov". In the end, claimed Nikiforov, "the entire business was controlled by Cherkasskii and Poliakov, and there was nothing left for us to do but sell our shares because we did not have any influence"13.

While Lazar's financial success owed much to favorable market conditions, his connections to high officials, most famously his legendary ties to Prince Vladimir Andreevich Dolgorukov, general governor of Moscow, were entirely due to his mastery of establishing contacts. As Zinaida's diaries show, Lazar nurtured those ties to Dolgorukov and others in high society by relying on the social labor of his wife and daughters, who helped make the political intimacy personal and authentic. That personal nexus was evident in Zinaida's entry for 6 July 1884: "Dolgorukov (among others) came for lunch on Tuesday for Mother's birthday"14. The Poliakov-Dolgorukov ties were well known. Roza Vinaver, the daughter of a wealthy merchant, recalled the reaction of Moscow Jews to the assassination of Alexander II (which aroused fears of pogroms): “The fact that Dolgorukov was friends with the Jewish banker, Lazar Poliakov, had an especially soothing effect on my childish imagination. We children were convinced that no one could touch us as long as Dolgoru-

9 Poliakov I. Istoriia semeinykh nachinanii. L. 82.

10 Anan'ich B. V., Beliaev S. G. St. Petersburg: Banking Center of the Russian Empire // Commerce in Russian Urban Culture 1861-1914 / eds W. C. Brumfield, B. V. Anan'ich, Y. A. Petrov. Baltimore, 2002. P. 19.

11 On the Old Believers' hostility toward the state and tsar, see: Robson R. Old Believers in Modern Russia DeKalb, 1995.

12 V. A. Cherkasskii was an influential figure in Moscow and served as the city mayor (1869-1871).

13 Nikiforov D. Moskva v tsarstvovanie imperatora Aleksandra II. Vospominaniia. Moscow, 1904. P. 144-147. - Lazar remained the head of the Moscow Land Bank Board until his death in 1914, at which point his son Isaak took over his position.

${ }^{14}$ Freeze C. Y. A Woman of Distinction: The Life and Diaries of Zinaida Poliakova. P.249. 
kov went to the Poliakovs for dinner" ${ }^{15}$. Another memoirist, B. A. Shchetinin, wrote that the Poliakovs were "indispensable" guests at Dolgorukov's lavish balls "with [their] sea of champagne, the tried and true Riabov orchestra, and magnificent live flowers from Nice". "Malicious tongues" wagged that Poliakov had opened an account for Dolgorukov "in his Land Bank for any sum", and gossips claimed that Poliakov's largesse was irresistible to Dolgorukov, who "loved to live in grand style, and to exercise charity with a generous hand". Dolgorukov, in turn, purportedly allowed Zinaida's mother to open a winter ball to show gratitude to her husband for helping his "adjutant with his debts" 16 . In short, this intimacy - derided by critics as commercial and corrupt - was an important factor in the family's social prominence and access to political power.

After Zinaida's marriage to Reuben Gubbay (grandson of Sir Albert Abdullah Sassoon), she nurtured the family's intimacy with political elites abroad at her fashionable salon on Avenue du Bois de Boulogne. French aristocratic salons not only persisted after 1789 but made haut monde "more distinctive and attractive as a cultural model" at a time when the power of the aristocracy was in a precipitous decline ${ }^{17}$. The salon was an instrument for social assertion, not mere survival ${ }^{18}$. As in earlier times, the salon helped to "link private interests to political power and public influence" 19 . A report in Le Figaro on 17 March 1904 graphically shows how Zinaida's salon served Poliakov family interests: "On Monday, Madame Reuben Gubbay gave a brilliant dinner party with twenty-four place settings in honor of His Excellency, Monsieur Kartsov, the very distinguished Consul General of Russia in Paris, who learned the day before about the exploits of his son at Port Arthur"20. Zinaida entertained family business associates, such as the Proppers (a prestigious banking family from Prague) ${ }^{21}$, the businessmen Henri and Philippe Brüll ${ }^{22}$, and the English stockbroker Alex Waley and his wife Marguerite (regular guests at the Gubbay home). Marguerite indeed was Zinaida's close friend and the granddaughter of Léopold Louis-Dreyfus, who had established a lucrative trading house in Basel in 1851 and built an expansive network in Eastern Europe and Russia ${ }^{23}$. Iakov Poliakov's diaries regularly report seeing various members of the Dreyfus family at the Gubbays ${ }^{24}$. The presence of

15 Vinaver R.G. Vospominaniia (unpublished memoir, Hoover Institute Archives [Stanford, California], Collection V. Maklakov. B. 15. Fol. 3, 9. - See also: Freeze C. Y. The Evolution of Roza Georgievna Vinaver: The Making of a Jewish Liberal Politician's Wife in Imperial Russia // The Individual in History / eds ChaeRan Y. Freeze, S. F. Fried, E. Sheppard. Waltham, 2015. P.317-334.

16 Poliakoff A., Sacks D. The Silver Samovar: Reminiscences of the Russian Revolution. Moscow; Nottingham, 1996. P. 23.

17 Kale S. D. Women, the Public Sphere, and the Persistence of the Salon // French Historical Studies. 2011. Vol.25, no. 1. P. 142

18 Ibid.

19 Ibid. P. 146.

20 Salons // Le Figaro. 17 March 1904.

21 Iakov Poliakov also underscored the ties to the Proppers, as in this entry from 11 April 1903: "I met with Propper in Vienna; he passionately praised Samuil [Iakov's youngest son]." See: Poliakov I. Istoriia semeinykh nachinanii. L. 360.

22 In 1906, Zinaida wrote that Philipp Brüll was at their home for business negotiations with her father to combine his three banks into one commercial company. (Nauchno-issledovatel'skii otdel rukopisei. Rossiiskaia gosudarstvennaia biblioteka (hereafter NIOR RGB). F. 743. K. 139. D. 1. L. 88 ob.)

23 Grange C. Une élite parisienne: Les familles de la grande bourgeoisie juive, 1870-1939. Paris, 2016. P. 91.

24 On Iakov Poliakov's difficult Azov-Don Bank affairs with Ruben and Constant Dreyfus, see: Poliakov I. Istoriia semeinykh nachinanii. L. 156, 157, 171 (entries from 1892 and 1893). "In general, the Drey- 
such illustrious banking families at Zinaida's salon appeared in the societal pages of leading newspapers and generated favorable - and valuable - publicity for the Poliakovs.

That publicity became all the more important when the Poliakov fortunes began to fail. By the late 1890s, the Poliakov financial empire was perilously overextended and, despite Lazar's attempts to conceal losses, his enormous assets were quickly turning into enormous debts. Indeed, Lazar's business acumen left much to be desired. A perfect example of poor judgment was his decision in 1889 to build a match factory in Tehran for 400,000 rubles: because of its ill-advised location (far from cheap supplies of wood), the inferior quality of the matches, and high production costs, the Poliakov matches simply could not "compete with the Austrian import" 25 . Rather than cut his losses, however, Lazar chose to expand operations, and in 1893 he used capital from his Moscow International Bank to enter the Persian cotton market. His losses rapidly snowballed. To hide the red ink, Lazar resorted to bookkeeping tricks: he bought a textile mill in Pärnu (which was neither incorporated nor even fully built), had the mill purchase three of his unprofitable Persian cotton factories, and thereby reduced the book debt of his Persian and Central Asian Society ${ }^{26}$. Lazar even speculated on American cotton, with a scheme to buy cheap and sell dear in New York, Liverpool, and Alexandria. As long as the global markets were on the upswing, his enterprises managed to stay afloat and his global reputation remained strong. As one historian observes, a desperate Lazar plunged ever deeper into speculative ventures: he "mortgaged shares of his own companies at a preferential rate in his own banks, and immediately invested the bank loans he received into new stock-exchange transactions" 27 . But Lazar's risky machinations caught up to him in 1899, when European markets plunged into recession. That misery was compounded by bad timing: his Moscow State Bank's bonds came due in 1900 and 1901. The catastrophic losses caused the bank stockholders-three-quarters of whom were small investors - to demand that the government hold Poliakov accountable ${ }^{28}$.

In 1901, their complaints triggered an audit by the State Bank and the Special Chancellery of the Credit Division. The audit found that Lazar had inflated the book value of his securities and stocks and that his liabilities far exceeded his assets ${ }^{29}$. In a memorandum to Nicholas II in October 1901, Minister of Finance Sergei Witte warned that the heavy losses sustained by just three of the Poliakov banks (the Moscow International, Southern Russian, and Orlov Banks) could "lead Poliakov to bankruptcy" 30 . But the banks were not only too big but also too intimately connected to fail: Poliakov's ties to influential patrons and investors saved him. Elite supporters, like Witte, wrapped the defense of Poliakov in the seemly discourse of state interest: "The solvency [of private banks] is of interest not only to stock-holders but also depositors. $\langle\ldots>$ A cessation of payments by these banks, which have existed about thirty years, would ruin not only a multitude of depositors all across Russia, but would deal a heavy blow to private credit, undermining confidence in

fusses have cost me a lot in both money and health, and there is no accounting," Iakov wrote on 19 July 1895 (Poliakov I. Istoriia semeinykh nachinanii. L. 208).

${ }_{25}$ Anan'ich B. V. Bankirskie doma v Rossii. P. 200.

26 Ibid.

${ }^{27}$ Petrov Y. The Banking Network of Moscow at the Turn of the Twentieth Century // Commerce in Russian Urban Culture, 1861-1914 / eds W. C. Brumfield, B. V. Anan'ich, Y. A. Petrov. Baltimore, 2002. P. 56.

28 Anan'ich B. V. Bankirskie doma v Rossii. P. 122.

29 Ibid. P. 127.

30 Ibid. P. 125. 
private banks that has already been shaken"31. In short, warned Witte, Poliakov's problems threatened to precipitate an economic $\mathrm{crisis}^{32}$. Despite Nicholas II's express desire to remove the Poliakov Banking House and Poliakov himself "once and for all" from the picture and to liberate "Moscow from the Jewish den," that was not a viable option ${ }^{33}$. In the end, the committee decided to place the Poliakov Banking House under the State Bank, authorize it to service his debts, and thus keep his enterprises afloat. Hence Poliakov's "political capital" was crucial in saving his financial capital.

\section{Aristocratic Sociability}

To cultivate ties with investors and to project affluence and prominence, the Poliakovs actively engaged in aristocratic sociability. Although neither native Muscovites nor hereditary nobles, the Poliakovs instilled the culture of gentility in their children. Zinaida's mother employed the best tutors and governesses to ensure that her offspring received an elite education, and that included modern foreign languages (with an emphasis on Russian and French), music, and dance. As the diaries show, Zinaida and her siblings took music lessons from V.V. Bezekirskii (the talented violinist and concertmaster of the Bolshoi Theater orchestra) and famous pianists like Emiliia Isaakovna Ogus-Shaikevich, Max Erdmannsdörfer, and his wife Pauline (née Fichner).

For Zinaida, attending balls, soirées, social calls, and dinner parties represented a principal social responsibility. She was particularly fond of private balls, which allowed her to demonstrate her dancing skills and indulge in society gossip, an important performance of aristocratic intimacy. The balls also gave an opportunity to show off her latest fashions from Paris and thereby flaunt family wealth. On 1 March 1886, after receiving an invitation to one such ball, Zinaida mulled over what she might wear and decided she would wear her "blue silk dress, very beautiful, from the famous [Charles Frederick] Worth" ${ }^{34}$. The family even invoked its status as Russian elite at the Trinity-Sergius Monastery. Told that their party must wait until the conclusion of services to see the riches in its sacristy, the visitors insinuated ties to the imperial court, threatened to complain to the metropolitan - and "open sesame" - promptly gained admission to the sacristy ${ }^{35}$.

Performing their aristocratic identity meant ostentatious indulgence, not just for its own sake, but as a public display of creditworthiness, so important in a new age of unregulated private business. Travel abroad was an important part of this performance. The Poliakovs became regulars at the most prized - and pricey - spas and hotels in Europe. The society pages of European papers chronicled the Poliakovs' movements and the aristocratic company with whom they were traveling, as in this report for 2 January 1885 in the Deutsches Volksblatt: "Lazar Poliakov and family, who came from Paris, traveled with Princess Marie Dolgurukoff and Princess Sophie Scherbatoff, who came from Italy. The Russians are staying at the Hotel Imperial"36. Identified as distinguished "Russians" (with

31 Ibid.

${ }^{32}$ Malik H. Bankers and Bolsheviks: International Finance and the Bolshevik Revolution. Princeton, 2018. P. 179.

${ }^{33}$ Lebedev S. K. European Business Culture and St. Petersburg Banks // Commerce in Russian Urban Culture. P. 129.

${ }^{34}$ Freeze C. Y. A Woman of Distinction: The Life and Diaries of Zinaida Poliakova. P. 284.

35 Ibid. P. 251-252.

36 Report // Deutsches Volksblatt. 2 January 1895. 
no allusion to their Jewishness), the Poliakovs had publicly established themselves as part of a transnational aristocratic elite.

Aristocratic sociability with Russians, however, did not extend to marriage, and the Poliakovs relied on their transnational networks to marry off their children to members of the Jewish elite in Western Europe. The family sought eligible Jewish partners at the resorts and spas - Jewish hives of Jewish matchmaking - where Zinaida met her future husband Reuben Gubbay" 37 ."We spent five months abroad. So I was two and a half months with Mama in Paris after the treatment in Franzensbad and in Nachhut [sic] in the Swiss mountains) and made a pleasant new acquaintance. I initially did not like the Gabbe [Gubbay] family, but later became close to them" 38 . Despite concerns that Gubbay intended to move to China to engage in his family's business, the family concluded the betrothal in 1891 - an event reported in the international newspapers that highlighted the brilliant match between the daughter "of a rich Russian banker of Moscow" and "the grandson of Sir Albert Sassoon" 39 . Zinaida's sisters and cousins even married into titled aristocratic families like the de Hirschs in Germany and the Levys in Italy ${ }^{40}$. Transnational marriages cemented the Poliakov family's status and prestige both in Russia and abroad.

\section{Cultural Intimacy}

Patronage of the arts was also critical to the Poliakovs' performance and identity as members of the imperial elite ${ }^{41}$. The renown of Zinaida's mother for her munificence even appeared in an obituary published in far-away America in 1919: "Thanks to her generosity as well as that of her husband, Moscow was endowed with museums and art treasures" 42 . Zinaida's parents were generous benefactors of the Museum of Fine Arts in Moscow (now the Pushkin State Museum of Fine Arts) as an imperial institution for the general public and the advancement of art education. Its founder, Ivan Tsvetaev, a professor at Moscow University, sought to raise funds by naming exhibition halls in honor of donors. Whereas most Moscow merchants who spurned his call (whether from niggardliness or cultural conservatism), Lazar Poliakov promptly agreed and publicly supported Tsvetaev's project: "Owing to Your Excellency's letter of 28 May, I have the honor to report that, sympathizing with the useful goal of building of a Museum of Fine Arts (in honor of Emperor Alexander III) at the Moscow Imperial University, I expressed my wish to donate a sum of 22,944 rubles for the building of exhibit hall No. 12 (for Greek relief sculptures from the $5^{\text {th }}$ and $6^{\text {th }}$ centuries BCE)" 43 . The Poliakov name was duly inscribed on the wall of the Greek exhibition hall.

37 On Jewish spa culture, see: Zadoff M. Next Year in Marienbad: The Lost Worlds of Jewish Spa Culture. Philadelphia, 2012.

38 Freeze C. Y. A Woman of Distinction: The Life and Diaries of Zinaida Poliakova. P. 268.

39 Carnet de marriage // Le Figaro. 25 July 1891; Times of India. 25 July 1891; Echos Mondains // New York Herald, Paris. 25 July 1891.

${ }^{40}$ For more on the marriages of Zinaida's siblings and relatives, see: Freeze C. Y. A Woman of Distinction: The Life and Diaries of Zinaida Poliakova. P. 54-57.

${ }^{41}$ Bowlt J. The Moscow Art Market // Between Tsar and People: Educated Society and the Quest for Public Identity in Late Imperial Russia / eds E. Clowes, S. Kassow, J. West. Princeton, 1991. P. 108. P. 379 .

${ }^{42}$ Obituary of Madame de Poliakoff // The Advocate: America’s Jewish Journal. 22 November 1919.

${ }^{43}$ Lobovskaia P. Poliakovskii zal v Musee iziashchnykh iskusstv v Moskve // Vestnik evreiskogo universiteta v Moskve. 1913. No.3. P. 135. 
Significantly, the Poliakovs also supported Jewish artists like the sculptor Marc Antokolsky, a frequent guest in their home and a prominent figure in Zinaida's diaries. Antokolsky was an artist of some renown and received awards for his work at the Paris World Exhibition in 1878. In 1884, the intrepid Zinaida - an admirer of the imperial family sought to impress Antokolsky with her own sculpture of Alexander II: "The guest now is Antokolskii, who is simultaneously making the busts of Mama and Papa. I also made my first attempt at sculpting (a bas-relief of the late emperor) - which people say was not so bad. <...> I shall try to justify Mr. Antokol'sky's opinion that I have a talent for making models" 44 . The Poliakov patronage of Antokolsky helped to expand the supra-ethnic boundaries of imperial art and elicited high critical opinion. In an article about "TwentyFive Years of Our Art," the critic Vladimir Stasov observed that Antokolsky had created many impressive sculptures, but that his full-body statue of Samuel Poliakov shows "a real living person. In its life-like naturalism, simplicity, the astonishing reality of the body and dress, this statue has no parallel in all of European sculpture" ${ }^{35}$. The Poliakovs could have asked for no better compliment or public recognition of their prominence.

The Poliakovs also hired leading Russian architects to design their houses, banking buildings, and even the family synagogue. For the latter they chose Dmitrii N. Chichagov, known for his modern, nationalistic, and eccentric designs. Zinaida's brother was unhappy with the choice: "Iliusha expresses sharp criticism of the architectural shortcomings of the new house of worship and is even excessive in his abuse of its builder, Chichagov." Yet Zinaida had her own doubts as to whether Chichagov was "really qualified to design a Jewish synagogue: he himself is Orthodox and has hardly seen such buildings"46. But Lazar's risky decision earned critical praise, even in Jewish quarters; the Hebrew newspaper Hamelits lauded the grandeur of the "Temple of the Lord of Hosts" and went on to add this personal note: "I went to pray there, and what a very marvelous thing it was to view this building from within and without". The author described the tall, quadrangular edifice, which was "pleasing to the eye" and the ornate luhot habrit (tablets of the covenant) engraved with the Ten Commandments in gilded Hebrew letters that stood above the arched entrance $^{47}$. Sensitive to the aesthetics of the sacred music at the synagogue, the Poliakovs hired Nahum Maten'ko from Odessa (who graduated from the Moscow Conservatory), and the latter's magnificent alto-baritone voice even attracted Christians like the Katkovs to the Friday evening services ${ }^{48}$. Built in the heart of an elite Moscow district, the synagogue demonstrated that Judaism was as much a part of the imperial fabric as Russian Orthodoxy.

Like any good aristocratic family, the Poliakovs purchased season tickets to the ballet and opera ${ }^{49}$. Opera afforded an opportunity not only to socialize with elites but also to experience national belonging, especially when attending patriotic Russian operas like Mikhail Glinka's A Life for the Tsar. On 9 February 1887 Zinaida wrote that the prima donna Aleksandra Panaeva-Kartseva (1853-1942), "who will debut in the role of Antonina," had sent them tickets for the performance. Later, when living in Paris, Zinaida continued

${ }^{44}$ Freeze C. Y. A Woman of Distinction: The Life and Diaries of Zinaida Poliakova. P. 254.

45 Stasov V. V. Dvadtsat' piat' let nashego iskusstva // Izbrannye sochineniia v trekh tomakh. Zhivopis'. Skul'ptura. Muzyka. Moscow, 1952. P. 498.

${ }^{46}$ Freeze C. Y. A Woman of Distinction: The Life and Diaries of Zinaida Poliakova. P. 282.

${ }^{47}$ Leyisharim naveh tehilah // Hamelits. 23 August 1886.

48 Freeze C. Y. A Woman of Distinction: The Life and Diaries of Zinaida Poliakova. P. 349.

49 Buckler J. A. The Literary Lorgnette: Attending Opera in Imperial Russia. Stanford, 2000. P. 8. 
to cultivate ties to artists, musicians, and theater celebrities to cement her place in cultured society. Like the French aristocracy, her family continued to "deploy social and symbolic forms of capital" by providing patronage for the performing $\operatorname{arts}^{50}$. Zinaida often invited artists to perform at her salon to promote their plays. For instance, on 13 March 1903, Gil Blas announced "a soirée de comédie at Madame Reuben Gubbay's salon on Avenue du Bois de Boulogne ${ }^{51}$. On 14 March 1903, La Presse promised that the guests of "this charming hostess" would be treated to "a performance of a small scene about the montmartrois [the inhabitants of Montmartre]"52. Zinaida also accepted invitations from Princess Maria Della Rocca ${ }^{53}$ to musical matinees, including a performance by the English singer Madame Florence Meredith ${ }^{54}$. After Zinaida attended "a very good matinee at the publisher's [of] Le Figaro," where the Spanish violist Pablo de Sarasate performed along with many other artists, Zinaida candidly admitted: "It goes without saying that the main attraction of this [event] is that they will publish the names of the invited [guests] the next day" 55 . Visibility in the art world was critical for the Poliakovs' determination to demonstrate their aristocratic culture and magnanimity.

\section{Elite Philanthropy}

The Poliakov's capital allowed them to engage in philanthropic activities that emulated aristocratic practices and enabled entre into high society. Their charitable activities included the construction of hospitals (acutely needed in an under-medicalized country) and donations to high-quality educational facilities (such as the Katkov Lyceum, where a close friendship to Mikhail Katkov earned admission for Lazar's sons) ${ }^{56}$. The Poliakov contributions to Russian hospitals and schools at a time of discriminatory quotas for Jews prompted Jewish critics to complain that the Poliakovs took more interest in imperial institutions than in the Jewish community (which was hardly fair, given the family's substantial donations to Jewish charities and institutions). But the Poliakovs were particularly generous to charities associated with the royal family, such as the Imperial Russian Music Society $^{57}$ and the Imperial Philanthropic Society ${ }^{58}$, as well as personal charities of well-

${ }^{50}$ MacKnight E.C. Faith, Fortunes, and Feminine Duty: Charity in Parisian High Society, 18801914 // Journal of Ecclesiastical History. 2007. Vol.58, no. 3. P. 486.

51 Réceptions mondains // Gil Blas (13 March 1903).

52 Nos Echos // La Presse. 14 March 1903.

${ }^{53}$ Maria Embden Heine, niece of the German-Jewish writer Heinrich Heine.

${ }^{54}$ NIOR RGB. F. 743. K. 138. D. 3. L. 26 ob. (9 May 1903).

55 NIOR RGB. F.743. Op. 138. D. 3. L. 24 ob. (6 May 1903). - She also hosted a dinner party at which Madame Roth "sang some songs of Schumann and Schubert after dinner" (Le monde, salons // Gil Blas (12 January 1905)).

56 Konstantin Pobedonostsev wrote to Alexander III that Katkov had made efforts to secure subsidies for his school from P. M. Leont'ev and "mainly S[amuel] S[olomonovich] Poliakov." See: Pobedonostsev K. P. Pis'ma k Aleksandru III. Moscow, 2014. Vol. 1. P. 401. - As Sergei Witte observed: "In general, Katkov had nothing against the Jews and not only had nothing against [them], but even had good relations with the Jews. So, for example, the Katkov Lyceum in Moscow (the so-called Lyceum of the Tsarevich Nicholas) was founded with considerable assistance from Poliakov and Jewish money in general". (Iz arkhiva S. Iu. Vitte: Vospominaniia / eds B. V. Anan’ich, R. Sh. Ganelin. St. Petersburg, 2003. Vol. 1. P. 283).

57 Otchet Moskovskogo otdeleniia imperatorskogo russkogo muzykal'nogo obshchestva, 1904-1905. Moscow, 1906. P. 25.

${ }^{58}$ Vsepoddanneishii otchet soveta Imperatorskogo chelovekoliubivogo obshchestva za 1904 god. St. Petersburg, 1904. P. 109. 
placed nobles. Iakov proudly recorded that he "received several heartfelt letters" after a 500 -ruble donation to a V.P. Meshcherskii philanthropy ${ }^{59}$. His donations to the charities of K.P. Pobedonostsev's wife made him welcome in their home - or at least he so believed, with this frequent refrain in his diary: "I was at Madame and Monsieur Pobedonostsevs'. As always, they were infinitely courteous" 60 . The Poliakovs and Pobedonostevs even vacationed together abroad. For instance, in 1897, Iakov's diary recorded their shared time at the spas of Carlsbad and Marienbad:

21 July 1897 [Carlsbad]: Madame Pobedonostsev herself came up to my wife to become acquainted with her; it went well.

24 July 1897: I walked and had coffee with the Pobedonostsevs.

26 July 1897: I was at the theater with the Pobedonostsevs.

29 July 1897 [Marienbad]: The Pobedenostsevs were at my place and then we were at the theater.

30 July 1897: I accompanied the Pobedenostsevs to the train station; the farewell was heartfelt. They both asked me to send regards to my wife ${ }^{61}$.

This association with such archconservatives, better known for their antisemitic views, seems surprising, to say the least. But these close personal ties reflected not only philanthropic interests and personal ties, but also shared political views - above all, an aversion to the revolutionary movement, with its terrorism and socialism.

As a reward for their imperial philanthropy, the Poliakovs eventually acquired the status of hereditary nobility - to be sure, after years of tireless campaigning. On 20 May 1897 Iakov wrote triumphantly: "I received congratulations from [my children] Lazar, Boris, Samuil, and Annette that the sovereign has approved Markovich's report and granted me and [my brother] Lazar the right and privilege of the rank of active privy state counselor and, through the Order of Anna Stanislav of the first degree, hereditary nobility. Thank God, finally!" The next day, a bit more soberly, he confessed the exorbitant cost: "But a lot of expenditures - all preliminary and unsuccessful. I promised Markovich to contribute 25,000 rubles to the [Imperial] Philanthropic Society. Nevertheless, I least of all expected to receive [the status of nobility] through him, so I made persistent efforts through so many highly placed people but did not succeed; no matter whom I asked, no matter who acted on my behalf, no matter what means were employed, it was all in vain. God helped and Markovich did it, thank God"62. Now the family's legal status matched the surname "de Poliakoff" that they had been unabashedly using when abroad.

Despite the Poliakovs' intimacy with elite society, their acceptance had boundaries: antisemitism in the bureaucracy and conservative Russian newspapers (some owned by close Poliakov friends) was a constant reminder that they were not fully accepted. Despite

59 Poliakov I. Istoriia semeinykh nachinanii. L. 165.

60 Ibid. L. 140-141.

${ }^{61}$ Ibid. L. 235-236. - The ties between the Poliakovs and Pobedonostsev date back to the 1870s when Samuil Solomonovich Poliakov submitted his first petition to donate a two-story building and funds to establish a school of the Russian Voluntary Fleet - a Pobedonostsev hobbyhorse. Pobedonostsev brought the petition to the attention of Alexander III. See: Pobedonostev K. P.: 1) Konstantin Petrovich Pobedonostsev i ego korrespondenty. Minsk, 2003. Vol. 1. P. 18-19; 2) Pis'ma k Aleksandru III. Moscow, 2014. Vol. 1. P. 180, 252-253. - In turn, Pobedonostsev actively supported Samuil Poliakov's plan to build railroads in Turkey, Bulgaria, and Persia as a ploy to counter the British (who were being supported by the Austrians). See: Pobedonostsev K. Pis'ma k Aleksandru III. Vol. 1. P. 122-125.

${ }^{62}$ Poliakov I. Istoriia semeinykh nachinanii. L. 232. 
this antisemitic current (perhaps because of it), Lazar Poliakov made lavish contributions to projects being promoted by the editor of an archconservative, antisemitic newspaper, V.P. Meshcherskii of Grazhdanin. In the 1880s, Meshcherskii published a series of articles that blamed Russia's economic woes on what he called the Jewish plutocracy and demanded reform "to centralize the credit system in a state bank" so that the "mass of the people's capital $\langle\ldots\rangle$ would not go into the bottomless pockets of the zhidy, plutocrats, and other swindlers [here] and abroad" 63 . Meshcherskii himself, of course, had no qualms about taking rubles from those very "bottomless pockets" that he denounced ${ }^{64}$. Outraged by the unholy alliance of Poliakov and Meshcherskii, the Jewish press did not mince words. In its coverage of the fiftieth anniversary of Meshcherskii's Grazhdanin, the Yiddish daily Der Fraynd made transparent insinuations about Meshcherskii's rumored homosexual philandering in its lead article, “The Great Love.” It also questioned how Poliakov could congratulate the "antisemitic publicist" and how he could express the hope that the newspaper "would flourish for many years for the good of society." Asking "Is Poliakov a Jew?" it concluded: "He's more a financial magnate than a Jew" ${ }^{65}$. Lazar's connection to Meshcherskii even made headlines in New York: "Poliakov sends a blessing to Prince Meshcherskii." It reported that Poliakov wished the "famous Judeophobe [Yid. yidn freser]" a long life so that "he can continue his 'useful work' - that is, besmirch Jews" 66 . Despite the Poliakovs' close ties to European Jewish elites, they had a far less enviable reputation among other segments of Jewish society. The transnational performance produced valuable PR among elites (Jewish and non-Jewish), but had quite the contrary effect among Jews outside those intimate circles of the haut monde.

In conclusion, the complicated calculus of capital, aristocratic sociability, and cultural patronage facilitated the Poliakov family's intimacy with Russian high society at home and abroad. The Poliakovs labored to establish their credentials as members of the Russian elite but also sought to strengthen ties with Jewish elites, especially in Europe. The latter, after all, proved critical, not only for business, but for finding suitable spouses since the Poliakovs did not regard intermarriage as an option. The transnational was thus not only a matter of business and investment, but served to showcase the Poliakovs as members of imperial Russian and transnational Jewish elites.

\section{References}

Anan'ich B. V. Banking houses in Russia, 1860-1914. Moscow: ROSSPEN Publ., 2006, 293 p. (In Russian) Anan'ich B. V., Beliaev S. G. St. Petersburg: Banking Center of the Russian Empire. Commerce in Russian Urban Culture 1861-1914. Eds W. C. Brumfield, B. V.Anan'ich, Y. A. Petrov. Baltimore, John Hopkins Press, 2002, pp. 9-20.

Bowlt J.E. The Moscow Art Market. Between Tsar and People: Educated Society and the Quest for Public Identity in Late Imperial Russia. Eds E. Clowes, S. Kassow, J. West. Princeton, Princeton University Press, 1991, pp. 108-128.

${ }^{63}$ Op. cit. Dronov I.E. Razrabotka konservativnnoi kontseptsii razvitiia Rossii v tvorchestve V.P. Meshcherskogo. Dis. ... kand. ist. nauk. Moscow, 2002. P. 208.

${ }^{64}$ Grazhdanin. 1889.27 September. Iakov Poliakov also claimed to be very close to Meshcherskii, as in this diary entry: "Meshcherskii gave a dinner to all those who congratulated him on his twenty-fifth jubilee. He treated me most graciously" (Poliakov I. Istoriia semeinykh nachinanii. L. 239 (14 January 1897)).

65 T.D. G. Di groyse libe // Der Fraynd. 2 February 1910. P. 2.

66 Poliakov shikt a brokhe tsu kniaz Meshcherski // Der morgen zhurnal. 15 February 1910. P. 1. 
Buckler J. A. The Literary Lorgnette: Attending Opera in Imperial Russia. Stanford, Stanford University Press, 2000, $294 \mathrm{p}$.

Freeze C. A Woman of Distinction: The Life and Diaries of Zinaida Poliakova. Waltham, Brandeis University Press, 2019, $384 \mathrm{p}$.

Grange C. Une élite parisienne: Les familles de la grande bourgeoisie juive, 1870-1939. Paris, CNRS Éditions, 2016, $547 \mathrm{p}$

Kale S.D. Women, the Public Sphere, and the Persistence of the Salon. French Historical Studies, 2011, vol. 25, no. 1, pp. 115-148.

Lebedev S. K. European Business Culture and St. Petersburg Banks. Commerce in Russian Urban Culture. Eds W. C. Brumfield, B. V. Anan'ich, Y. A. Petrov. Baltimore, John Hopkins Press, 2002, pp. 21-38.

Lobovskaia P. Polyakov Hall at the Museum of Fine Arts in Moscow. Vestnik Evreiskogo universiteta $v$ Moskve, 1913, no.3, pp.133-136. (In Russian)

Lowe L. The Intimacies of Four Continents. Durham, Duke University Press, 2015, 328 p.

Malik H. Bankers and Bolsheviks: International Finance and the Bolshevik Revolution Princeton, Princeton University Press, 2018, 318 p.

Petrov Y. The Banking Network of Moscow at the Turn of the Twentieth Century. Commerce in Russian Urban Culture, 1861-1914. Eds W. C. Brumfield, B. V.Anan'ich, Y. A. Petrov. Baltimore, John Hopkins Press, 2002, pp. 48-58.

Pobedonostsev K. P. Pis'ma k Aleksandru III: 2 vols. Vol. 1. Moscow, Direkt-Media Publ., 2014, 460 p. (In Russian)

Pobedonostsev K.P. Konstantin Petrovich Pobedonostsev and his correspondents: 2 vols. Vol.1. Minsk, Kharvest Publ., 2003, 446 p. (In Russian)

Poliakoff A., Sacks D. The Silver Samovar: Reminiscences of the Russian Revolution. Moscow, Nottingham, Atlantida Press Publ., 1996, 140 p.

Robson R. Old Believers in Modern Russia. DeKalb, Northern Illinois Press, 1995, 188 p.

Stasov V.V. Twenty Five Years of Our Art. Izbrannye sochineniia $v$ trekh tomakh. Zhivopis'. Skul'ptura. Muzyka. Moscow, 1952, pp. 5-183.

Stoler A.L. Intimidations of Empire: Predicaments of the Tactile and Unseen. Haunted by Empire: Geographies of Intimacies in North American History. Ed. by A. L. Stoler. Durham, Duke University Press, 2006, pp. 1-22.

Wilson A. Infrastructure of Intimacy. Signs, 2016, vol. 42, no. 2, pp. 247-280.

Zadoff M. Next Year in Marienbad: The Lost Worlds of Jewish Spa Culture. Philadelphia, University of Pennsylvania Press, 2012, 310 p. 